\title{
Phytochemical and pharmacological aspects of Tephrosia genus: A brief review
}

\author{
Vimal John Samuel ${ }^{1 *}$, Agasa Ramu Mahesh ${ }^{2}$, Vedigounder Murugan ${ }^{2}$ \\ ${ }^{1}$ Department of Pharmacology, College of Pharmaceutical Sciences, Dayananda Sagar University, Bengaluru, India. \\ ${ }^{2}$ Department of Pharmaceutical Chemistry, College of Pharmaceutical Sciences, Dayananda Sagar University, Bengaluru, India.
}

\begin{tabular}{l}
\hline ARTICLE INFO \\
\hline Received on: $21 / 01 / 2019$ \\
Accepted on: $15 / 03 / 2019$ \\
Available online: $30 / 03 / 2019$
\end{tabular}

Key words:

Tephrosia, Fabaceae, traditional medicines, phytochemical, pharmacology.

\begin{abstract}
Tephrosia, the plant genus belongs to the family Fabaceae. It belongs to the major group of angiosperms (flowering plants) that comprises more than 350 species which is widely distributed in the regions of tropical and subtropical countries of the world. Since the herbal medicine is in demand due to its fewer associated side effects, the genus Tephrosia is extensively used for the treatment of large number of diseases in traditional medicines. The main aim of this review is to summarize and document the phytochemical and pharmacological activities performed on Tephrosia genus. To promote the continual use of these plants and in order to plan for the future studies, it becomes important to provide a basis by combining a number of available information into a single data covering the different aspects of the plant.
\end{abstract}

\section{INTRODUCTION}

From many decades, plants have been used for the ailment of diseases. Traditional medicines refer to innumerable approaches such as animal- and mineral-based medicines, spiritual therapies, knowledge and beliefs in incorporating plant to treat, diagnose and prevent illness of the well-being. Most of the modern medicine currently used for various treatments has many undesirable effect and unpredictable pharmacological action; hence, the need to search for the newer drugs with lesser or no side effects is obligatory (Muazu and Kaita, 2008; Roger and Brian, 1996). Tephrosia genus belongs to the family Fabaceae (Leguminosae) and subfamily Paplilionaceae, which contains about more than 350 species of the genus. The plants in this genus are chiefly distributed in the regions of tropical, subtropical, and arid regions of the world (Al-Ghamdi, 2013). The plants are erect

"Corresponding Author

Vimal John Samuel, Department of Pharmacology, College of

Pharmaceutical Sciences, Dayananda Sagar University, Bengaluru, India.

E-mail:vimalalina@gmail.com herbs, or it is in the form of soft or woody shrubs. Based on several studies conducted by the taxonomist, Tephrosia was classified into four sections, namely, Mundulea, Brissonia, Craccoides, and Reineria, out of which Mudulea and Reineria were represented in India. Later, the genus has been classified into three subgenera which includes Marconyx (includes T. tenuis), Brissonia (includes T. candida), and Reineria (includes rest of the species of Tephrosia) (Lakshmi et al., 2008).

Phytochemical investigations revealed the presence of a number of phytoconstituents. The bioactivity associated with the plant has been studied extensively, indicating the phytoconstituents present in the Tephrosia genus manifested various biological activities such as anti-diabetic, anti-ulcer, antidiarrheal, wound healing, anti-inflammatory, insecticidal, antiviral, anti-protozoal, anti-fungal, anti-plasmodial, and many other activities (Chen et al., 2014). Several literature surveys showed a very few or no reviews were available which correlates the data of phytochemical, pharmacological, and molecular properties of the genus Tephrosia together. Thus, the main purpose of this review is to cover completely and provide up-to-date knowledge of pharmacological and phytochemical research work carried out on this genus. 


\section{CHEMICAL CONSTITUENTS OF TEPHROSIA GENUS}

Various research studies have been carried out to study the chemical constituents of the variety of plants belonging to genus Tephrosia. Many of the organic compounds belonging to different classes have been isolated. Among many of the organic compounds isolated, some have been used for their pharmacological properties and some of them are still unknown for their effects. It was found that flavonoids were the most commonly isolated and identified compound in the genus, the other main classes of compounds include rotenoids, terpenoids, sterols, essential oils, and fixed oils. Not many research studies have been carried to indicate the presence of essential oil and fixed oil. For many of the taxonomists, Tephrosia purpurea, Tephrosia toxicaria, Tephrosia candida, Tephrosia elata, and Tephrosia villosa have been a sign of interest. Also, there are works done on the stereochemistry of the compounds, for example, a flavonoid from Tephrosia pumila called as Praecansone, exists in two isomers (Dagne et al., 1988). The various chemical constituents isolated from some of the Tephrosia genus are described in Table 1.

Many of the isolated compounds have been studied for their pharmacological actions. There are many chemical components mentioned under the Table 1 that are not studied under the genus Tephrosia but the literature survey suggested their presence in other genera. For instance, Pseudosemiglabrin, Flemichapparin, Caryophellene oxide, deguelin, pongamol, and lupeol possess platelet aggregation antagonism, anti-fungal, anti-cancer, anti-convulsant, and anti-inflammatory activities, respectively.

\section{PHARMACOLOGICAL ACTIVITIES OF PLANT FROM GENUS TEPHROSIA}

\section{Hepatoprotective activity}

The hydro-alcoholic extract of aerial parts of $T$. purpurea was studied for its hepatoprotective activity against arsenic induced hepatotoxicity which causes acute hepatic injury and hepatocellular necrosis, thereby causing leakage of cellular enzyme (Gora et al., 2014). The stem of T. purpurea were extracted using methanol and investigated for its hepatoprotective activity (Verma et al., 2017). The ethyl acetate fraction of ethanolic extract of T. purpurea was investigated for its hepatoprotective activity against carbon tetrachloride induced hepatocellular injury. In all the above investigations, it was observed that the extracts significantly reduced the serum alanine aminotransferase, aspartate aminotransferase, alkaline phosphatase, total bilirubin and also reduced necrosis and inflammation when compared with the toxic group. It was also observed that there was also a higher lipid peroxidation (LPO) and lower glutathione levels. These activities were due to the presence of polyphenolic compounds and flavonoids in the extracts of T. purpurea (Shah et al., 2011). The methanolic extract of Tephrosia calophylla also possesses hepatoprotective activity due to the presence of flavonoids (Adinarayana et al., 2011).

\section{Anti-diabetic activity}

The anti-diabetic activity of methanolic extract of $T$. calophylla was carried out both by in-vitro and in-vivo methods against alloxan-induced diabetes in albino Wistar rats. The results showed that there was a significant reduction in the blood glucose levels when compared with the diabetic control group. The extract was also effective in reducing the serum concentrations of serum glutamic oxaloacetic transaminase, triglycerides (TG), total cholesterol (TC) and urea, and increased insulin level. Tephrosia calophylla could also inhibit the in-vitro $\alpha$-glucosidase and $\alpha$-amylase activity (Ramesh and Rani, 2018).

The flavonoid rich fraction of the ethanolic extract of $T$. purpurea was used to evaluate the anti-diabetic activity (Bhadada and Goyal, 2016). The extract was well effective in providing the beneficiary effects on diabetes-induced cardiovascular complications as well as in the treatment of cataract and these activities may be attributed due to the presence of flavonoid, quercetin, and rutin present in this genus (Bhadada et al., 2016). The anti-diabetic activity of the silver nanoparticles using aqueous extract of Tephrosia tinctoria was tested and the results showed significant free radical scavenging ability, inhibition of carbohydrate digestive enzymes ( $\alpha$-Glucosidase and $\alpha$-amylase), and enhancement of glucose uptake rate (Rajaram et al., 2015).

\section{Anti-inflammatory activity}

Literature survey revealed the anti-inflammatory activity of ethanolic extract of the T. purpurea root using carrageenaninduced model. It was found that the inflammation was significantly reduced in the extract treated when compared with the inflamed group rats (Praveena et al., 2011). The ethyl acetate extract of $T$. sinapou was evaluated for the anti-inflammatory activity. The anti-inflammatory activity was proven by inhibiting the recruitment of total leukocytes and neutrophils, induced by a variety of inflammatory stimulus. This action may be attributed due to the presence of flavonoid and phenolic components present in the extract (Martinez et al., 2012). (-)-pseudosemiglabrin which is a major phytoconstituent isolated from Tephrosia apollinea possesses anti-inflammatory activity that was confirmed by measuring the levels of interleukin-1 (IL-1), tumor necrosis factor- $\alpha(\mathrm{TNF}-\alpha)$, and nitric oxide (NO) in in-vitro method. In-vivo activity was confirmed by the potential inhibition of granuloma tissue, thereby lowering the production of cytokines (Hassan et al., 2016).

\section{Anti-nociceptive activity}

Ethyl acetate extract of $T$. sinapou possessed antinociceptive effect when tested against acetic acid, phenyl-pbenzoquinone, formalin, and complete freund's adjuvant-induced writhing response by causing mast cell activation leading to the release of inflammatory cytokines (TNF- $\alpha$, IL- $1 \beta$, and eicosanoids) resulted in inhibition of inflammatory overt pain-like behavior in mice. The analgesic property was due to the presence of phenolic compound, thus proving promising anti-nociceptive activity (Martinez et al., 2012). The ethanolic extract of Tephrosia falcliformis root was screened for anti-inflammatory activity by three different models. The result revealed the reliving effect through peripheral action of the extract (Kumar et al., 2007).

\section{Wound healing}

Upon many literature surveys, researchers have even found the cutaneous wound healing (a complex physiological process) activity of ethyl acetate extract of $T$. purpurea. The extract 
Table 1. Chemical constituents from some of the plants of genus Tephrosia.

\begin{tabular}{|c|c|c|c|}
\hline Species & Class & Chemical constituents & References \\
\hline Tephrosia aequilata & Flavonoid & $\begin{array}{l}\text { 3,4:8,9-Dimethylenedioxypterocarpene, obovatin methyl ether, (E)-praecansone A, } \\
\text { Demethylpraecansone B. }\end{array}$ & (Atilaw et al., 2017) \\
\hline Tephrosia apollinea & Flavonoid & $\begin{array}{l}\text { (-)-Semiglabrin, (-)-Pseudosemiglabrin, (+)-Glabratephrinol, (+)-Glabratephrin, } \\
\text { Appollinine (7-methoxy-8- [3"-(2",5"-dihydro-5",5"-dimethyl-2"-oxofuryl)]-flavone, } \\
\text { Lanceolatin-A, Semiglabrinol, Tephroapollin C, D, E, F, G. }\end{array}$ & (Ahmed Hassan et al., 2014) \\
\hline Tephrosia barbigera & Flavonoid & Isopongaflavone, Barbigerone & (Touqeer et al., 2013) \\
\hline Tephrosia bidwilli & Flavonoid & $\begin{array}{l}\text { Tephrocarpin, (-)-6a } R ; 11 \mathrm{a} R \text {-maackiain, (-)-6aS; 11aS-pisatin, (-)-6a } R \text {; 11a } R \text {-4-methoxy- } \\
\text { maackiain, acanthocarpan }\end{array}$ & (Ingham and Markham, 1980) \\
\hline Tephrosia bracteolata & Flavonoid & Isopongaflavone, Trans-tephrostachin, Trans anhydrotephrostachin & (Babayemi and Bamikole, 2006) \\
\hline \multirow[t]{4}{*}{ Tephrosia calophylla } & Coumestan & Tephcalostan, Tephcalostan B, C, D & \multirow{4}{*}{$\begin{array}{l}\text { (Devi et al., 2017; Ganapaty } \\
\text { et al., 2009) }\end{array}$} \\
\hline & Flavonoid & 7-O-methylglabranin, Calophione A & \\
\hline & & kaempferol 3-O- $\beta$-D-glucopyranoside & \\
\hline & & $\begin{array}{l}\text { (2S)-5-hydroxy-7,4'-di-O- (gamma, gamma dimethylallyl)flavanone, 6-Hydroxy-E-3-(2,5- } \\
\text { dimethoxybenzylidine)-2',5'-dimethoxyflavanone, Kaempferol 3-O- } \beta \text {-D-glucopyranoside, } \\
\text { Tephrowatsin C, Afrormosin, }\end{array}$ & \\
\hline \multirow[t]{6}{*}{ Tephrosia candida } & Flavonoid & $\begin{array}{l}\text { Candidin, 6-Hydroxykaempferol 4'-methyl ether, Candidol, Tephrocandidin A, } \\
\text { Tephrocandidin B, Candidone, Ovalichalcone, Dehydrorotenone, } 12 \alpha \text {-Hydroxy- } \beta \text {-toxicarol, } \\
\text { Candirone, Candidachalcone, Tephrone, Tephrospirolactone, Tephrospiroketone I, II }\end{array}$ & \multirow[t]{6}{*}{ (Hegazy et al., 2011) } \\
\hline & Sterol & $\beta$-Sitosterol & \\
\hline & Sesquiterpenes & $1 \beta$-Hydroxy-6,7 $\alpha$-dihydroxyeudesm-4(15)-ene & \\
\hline & Acid & Caffeic acid & \\
\hline & Rotenoid & $\alpha$-Toxicarol, & \\
\hline & & $12 \alpha$-Hydroxyrotenone, Amorpholone & \\
\hline \multirow[t]{4}{*}{ Tephrosia cinerea } & $\begin{array}{l}\text { Flavonoids and } \\
\text { Phenolics }\end{array}$ & $\begin{array}{l}\text { Demethylapollinin 7-O- } \beta \text {-D-glucopyranoside, Apollinin, Glabatephrin, Semiglabrin, } \\
\text { Pseudosemiglabrin, Cineroside A }\end{array}$ & \multirow[t]{4}{*}{$\begin{array}{l}\text { (Arriaga et al., 2008; Maldini } \\
\text { et al., 2011) }\end{array}$} \\
\hline & & $\begin{array}{l}\text { 3'-O-methyl-quercetin 3,7-Di-O-rhamnopyranoside, Quercetin 3,7-di-O-rhamnopyranoside, } \\
\text { 3-O- } \beta \text {-xylopyranosylquercetin 7-O- } \alpha \text {-Rhamnopyranoside, } 3 \text {-O- } \alpha \text {-arabinopyranosylquercetin } \\
\text { 7-O- } \alpha \text { - rhamnopyranoside, } 5 \text {-O-methylgenistein } 7-O-\beta \text {-D-glucopyranoside, } \\
\text { Quercetin 3-O- } \beta \text {-glucopyronoside, Quercetin 3-O- } \alpha \text {-rhamnopyranoside, Kaempferol, } \\
\text { 7-O-methylquercetin }\end{array}$ & \\
\hline & Sesquiterpene & Caryophyllene oxide, Teclenone B & \\
\hline & Lignan & Pinoresinol & \\
\hline Tephrosia crassifolia & Flavonoid & Crassifolin, Crassichalcone & (Gomez-Garibay et al.,1999) \\
\hline Tephrosia elata & Flavonoid & $\begin{array}{l}\text { Isopongaflavone, Tephrosin, 8-(3,3-dimethylallyl)-5,7- dimethoxy flavanone, Obovatin } \\
\text { methyl ether, Elatadihydrochalcone, Obovatachalcone, }(S) \text {-elatadihydrochalcone }\end{array}$ & (Muiva et al., 2009) \\
\hline Tephrosia elongata & Flavonoid & Elongatin & (Smalberger et al., 1975) \\
\hline Tephrosia emoroides & Flavonoid & Emoroidone, 5-Methoxyisolonchocarpin, Emoroidocarpan, Emoroidenone & (Machocho et al., 1995) \\
\hline Tephrosia falciformis & Flavonoid & 7-Hydroxy-8-( $\gamma, \gamma$-dimethylallyl)flavanone, Falciformin. & (Khan et al., 1986) \\
\hline \multirow[t]{2}{*}{ Tephrosia fulvinervis } & Flavonoid & Fulvinervin $\mathrm{C}, \mathrm{A}, \mathrm{B}$ & \\
\hline & Rotenoid & $\alpha$-Toxicarol, Deguelin, Munduserone, Cis-12 $\alpha$-hydroxymunduserone, (-)-Maackiain & (Dagne et al., 1989) \\
\hline \multirow[t]{2}{*}{ Tephrosia hamiltonii } & Flavonoid & $\begin{array}{l}\text { 5,7-Dimethoxy-8-(2, 3-epoxy-3-methylbutyl)-flavanone, 2-Methoxy-3,9-dihydroxy } \\
\text { coumestone, Pongamol, Flemichapparin-B }\end{array}$ & \multirow[t]{2}{*}{$\begin{array}{l}\text { (Falak and Shoeb, 1987; Rajani } \\
\text { and Sarma, 1988) }\end{array}$} \\
\hline & & flemichapparin-C & \\
\hline \multirow[t]{2}{*}{ Tephrosia hildebrandtii } & Pterocarpan & Hildecarpidin, Hildecarpin & \multirow[t]{2}{*}{ (Lwande et al., 1986) } \\
\hline & Flavonoid & $\begin{array}{l}\text { methylhildardtol B, Hildgardtol B, Hildgardtene, Methylhildgardtol A, Hildgardtol A, } \\
\text { Trans-tephrostachin, Trans-anhydrotephrostachin }\end{array}$ & \\
\hline Tephrosia hookeriana & Flavonoid & Hookerianin, (-)-semiglabrin, Lanceolatin A, Tephrorianin & (Prabhakar et al., 1996) \\
\hline Tephrosia leiocarpa & Flavonoid & Tephroleocarpin A, Tephroleocarpin B & (Gomez-Garibay et al., 1991) \\
\hline Tephrosia lupinifolia & Flavonoid & $\begin{array}{l}\text { Lupinifolinol, Lupinifolinol triacetate, Lupinifolin, 5,4'-O,O-dimethyl-lupinifolin, } \\
\text { Lupinifolin diacelate }\end{array}$ & (Smalberger et al., 1974) \\
\hline Tephrosia madrensis & Flavonoid & 5,7-dimethoxy-8-prenylflavan & (Gomez-Garibay et al., 1983) \\
\hline
\end{tabular}




\begin{tabular}{|c|c|c|c|}
\hline Species & Class & Chemical constituents & References \\
\hline \multirow[t]{3}{*}{ Tephrosia major } & Flavonoid & 2',6'-dihydroxy-3'-prenyl-4'-methoxy- $\beta$-hydroxychalcone & (Gomez-Garibay et al., 2002) \\
\hline & Sterol & $\beta$-sitosterol, stigmasterol & \\
\hline & Triterpene & Lupeol & \\
\hline Tephrosia maxima & Flavonoid & Maxima flavanone A, Maxima isoflavone A, B, C, D, E, F, G, H, J & (Sandhya et al., 2011) \\
\hline Tephrosia multijuga & Flavonoid & Multijugin, Multijuginol & (Vleggaar et al., 1975) \\
\hline \multirow[t]{3}{*}{ Tephrosia pentaphylla } & Flavonoid & Dihydrostemonal, 9-Demethyldihydrostemonal, 6-Acetoxydihydrostemonal & (Dagne et al., 1989) \\
\hline & Rotenoid & Villosin, Sumatrol, Rotenone, $\alpha$-Toxicarol & \\
\hline & & cis-12 $\alpha$-hydroxyrotenone, 6 -Hydroxyrotenone & \\
\hline Tephrosia polyphylla & Flavonoid & 4'-Demethyltoxicarol isoflavone, Toxicarol isoflavone, 7-Methylglabranin & (Dagne et al., 1992) \\
\hline \multirow[t]{4}{*}{ Tephrosia procumbens } & Rotenoid & Rotenone, sumatrol, praecansone A, B, obovatin & (Venkataratnam et al., 1987) \\
\hline & & 7-ethoxy-3,3',4'-trihydroxyflavone; & \\
\hline & & Fisetin 7-ethyl ether & \\
\hline & & 7,4'-dihydroxy-3'-methoxyisoflavone & \\
\hline Tephrosia pumila & Flavonoid & Pumilanol, Pumilaisoflavone A, B, C, D $\beta$-hydroxychalcone, Praecansone-A & (Dagne et al., 1988) \\
\hline \multirow[t]{4}{*}{ Tephrosia purpurea } & Flavonoid & $\begin{array}{l}\text { Tephrosin, Pongaglabol, Purpureamethide, Pongamol, Karanjin, Lanceolatin B, } \\
(+) \text {-Tephrorins A, B, (+)-Tephrosone, Purpurenone, }(+) \text {-Purpurin, Purpuritenin, } \\
\text { Lanceolatin B, (+) Purpurin, Quercitin, }(-) \text {-Purpurin dehydroisoderricin, (-)-Maackiain } \\
\text { pseudosemiglabrin, (-)-semiglabrin, Terpurinflavone, (-)-Isolonchocarpin, 7,4'-Dihydroxy- } \\
3^{`}, 5^{`} \text {-dimethoxyisoflavone, }(+) \text {-Tephropurpurin }\end{array}$ & $\begin{array}{l}\text { (Khalafalah et al.,2010; Lodhi } \\
\text { et al., 2006; Peng et al., 2014) }\end{array}$ \\
\hline & & (-)-3-hydroxy-4-methoxy-8,9-methylenedioxypterocarpan & \\
\hline & & $(-)$-medicarpin & \\
\hline & & $\begin{array}{l}3 \text { '-methoxydaidzein desmoxyphyllin B, 3,9-Dihydroxy- } 8 \text {-methoxycoumestan, } \\
\text { Isoglabratephrin, Tephropurpulin A, Rutin, Serratin 7-O- } \beta \text {-D-glucopyranosyl- }(1 \rightarrow 4)-O-\beta \text { - } \\
\text { D-galoctopyranoside }\end{array}$ & \\
\hline Tephrosia semiglabra & Flavonoid & Glabratephrin, Semiglabrinol, Semiglabrin & (Smalberger et al., 1973) \\
\hline \multirow[t]{3}{*}{ Tephrosia sinapou } & Flavonoid & Toxicarine, Tephrowatsin A, Quercetol B, Flamichapparin B, 7-O-Methylglabranine, & (Martinez et al., 2016) \\
\hline & Rotenoid & $\begin{array}{l}\text { Tephrosin, rotenolone, rotenonone, villosone, 6a,12a-dehydrorotenone, 6-Oxo-6 } \alpha, 12 \alpha \text { - } \\
\text { dehydrodeguelin, 6-Oxo-6 } \alpha, 12 \alpha \text {-dehydro- } \alpha \text {-toxicarol }\end{array}$ & \\
\hline & Coumarin & 2,3-dihydro-p-coumaric acid & \\
\hline Tephrosia spinosa & Flavonoid & $\begin{array}{l}\text { Spinochalcone A, B, C, Spinoflavanones A, B, flemistrictin A, 3',5'-Diisopentenyl-2', 4'- } \\
\text { dihydroxychalcone, Fulvinervin A, Eupalitin 3-O-b-D-galactopyranoside }\end{array}$ & (Rao and Prasad, 1992) \\
\hline Tephrosia tinctoria & Flavonoid & $\begin{array}{l}\text { 7-O-methylglabranin, 5,7-Di-O-prenylbiochanin A, 2'-Hydroxy-7-methoxyflavonol, } \\
\text { Tephrowatsin C, Flemichapparin B, Kaempferol-3-O- } \beta \text {-D-glucopyranoside } \\
\text { dehydrorotenoid, Dehydrodeguelin, } 2 \phi \text {-Hydroxy-7-methoxyflavonol }\end{array}$ & $\begin{array}{l}\text { (Lakshmi et al., 2010; Reddy } \\
\text { et al., 2014) }\end{array}$ \\
\hline \multirow[t]{5}{*}{ Tephrosia toxicaria } & Flavonoid & Iso-obovatin, Obovatin, $\alpha$-Toxicarol, Sumatrol & (Ribeiro et al., 2006) \\
\hline & & $\begin{array}{l}6 \alpha, 12 \alpha \text {-dehydro- } \beta \text {-toxicarol, } 6 \alpha, 12 \alpha \text {-dehydro- } \alpha \text {-toxicarol, }(2 S)-5 \text {-hydroxy-7-methoxy- } 8 \text { - } \\
{[(\mathrm{E})-3 \text {-oxo-1-butenyl] flavanone, isoliquiritigenin, genistein, chrysoeriol }}\end{array}$ & \\
\hline & Coumarin & Marmesin & \\
\hline & Triterpene & Lupenone & \\
\hline & Rotenoid & 4',5'-Dihydro-11,5'-dihydroxy-4'-methoxytephrosin, 11-hydroxytephrosin & \\
\hline Tephrosia tunicata & Flavonoid & Tunicatachalcone & (Andrei et al., 2000) \\
\hline Tephrosia viciodes & Flavonoid & Enantiomultijugin & (Gomez-Garibay et al., 1992) \\
\hline \multirow[t]{4}{*}{ Tephrosia villosa } & Flavonoid & $\begin{array}{l}\text { (2S)-5,4'-dihydroxy-7-O-[(E)-3,7-dimethyl-2,6-octadienyl] flavanone, }(2 \mathrm{~S})-5,4^{\prime} \text {-dihydroxy- } \\
\text { 7-O-[(E)-3,7-dimethyl-2,6-octa-dienyl]-8-C-[(E)-3,7-dimethyl-2,6-octadienyl] flavanone, } \\
\text { 7-O-methylglabranin, } 12 \alpha \text {-dehydro-6-hydroxysumatrol, Tephcalostan, Villosin, Villosone, } \\
\text { Villol, Villinol, Tephrinone, }\end{array}$ & (Madhusudhana et al., 2010) \\
\hline & Triterpenoid & Lupenone & \\
\hline & Triterpene & Lupeol & \\
\hline & Sterol & Stigmasterol & \\
\hline Tephrosia viridiflora & Flavonoid & Viridiflorin & (Gomez-Garibay et al., 1985) \\
\hline
\end{tabular}




\begin{tabular}{|c|c|c|c|}
\hline Species & Class & Chemical constituents & References \\
\hline \multirow[t]{3}{*}{ Tephrosia vogelii } & Sesquiterpene & $(1 \beta, 6 \alpha, 10 \alpha)$-guai-4(15)-ene-6,7,10-triol, & (Stevenson et al., 2012) \\
\hline & Rotenoid & Deguelin, Tephrosin, Toxiconol, Tephrosal, & \\
\hline & Flavonoid & $\begin{array}{l}\text { Pyranosyl }(7 \rightarrow 6)-\beta \text {-galactopyranoside-7- } O \text { - } \alpha \text {-rhamnopyranoside, Pyranosyl }(1 \rightarrow 2) \\
{[\alpha \text {-rhamnopyranosyl }(1 \rightarrow 6)-\beta \text {-galactopyranoside, Rhamnopyranosyl }(1 \rightarrow 2)[(3-O-E \text { - }} \\
\text { feruloyl)- } \alpha \text {-rhamnopyranosyl }(1 \rightarrow 6)]-\beta \text {-galacto-pyranosides, }(2 R, 3 R)-3 \text {-hydroxy-5- } \\
\text { methoxy-6",6"-dimethylpyrano-[2",3":7,8]flavanone, }(2 S)-4 \text { '-hydroxy-5-methoxy-6",6"- } \\
\text { dimethylpyrano[2",3":7,8]-Flavanone, }(2 S) \text {-7-hydroxy-5-methoxy-8-prenylflavanone, } \\
(2 S)-5 \text {-methoxy-6",6"-dimethy1-4",5"-dihydrocyclopropa[4",5"]furano[2",3":7,8]flavanone, } \\
(2 S)-5,7 \text {-dimethoxy-8-(3-methylbut-1,3-dienyl)flavanone, Quercitin, }\end{array}$ & \\
\hline Tephrosia woodii & Flavonoid & Oaxacacin, Mixtecacin & (Chen et al., 2014) \\
\hline
\end{tabular}

was prepared and applied externally in the form of ointment $(5 \% \mathrm{w} / \mathrm{w})$ to rats. The study showed the extract processed healing action which was reflected by the improved collagen (predominant extracellular protein in granulation tissue of wounds) maturation by increased cross-linking and increased levels of hydroxyproline, a major constituent of collagen which serves as the indicator of replacement of collagen tissue, thereby promoting rapid wound healing process (Lodhi et al., 2006). Since flavonoids have been reported to have anti-oxidant and anti-inflammatory properties, $T$. purpurea is also believed to act as a health promoting substance and are reported to have important role in healing of wound (Lodhi et al., 2016).

\section{Anti-oxidant activity}

Chloroform and methanolic extract of T. calophylla was investigated for its anti-oxidant activity using albino Wistar rats. The result revealed an increase in the levels of catalase, superoxide dismutase and decrease in LPO which can be attributed due to its anti-oxidant mechanism. Flavonoid present in the extracts was responsible for its anti-oxidant mechanism (Ramesh and Rani, 2018). It was also discovered that the ethanolic extract of T. purpurea possessed anti-oxidant activity in an in-vitro study where it exhibited free radical scavenging in 1,1-diphenyl-2picrylhydrazyl (DPPH) assay and anti-lipid peroxidation properties in carbon-tetrachloride-induced LPO assay. Macrophages have been involved in the inflammation process and during the inflammation there is an increased production of superoxide ions. Many reports suggested the mild anti-inflammatory activities of T. purpurea. Based on these reports, researchers concluded that it may be possible that the inhibition of superoxide generation is related to anti-inflammatory activity of $T$. purpurea (Soni et al., 2006). The ethanol ether extract of Tephrosia vogelii seeds also showed anti-oxidant and free radical scavenging and this was mainly due to the presence of flavonoid present in the extracts (Li et al., 2010). The chloroform extract of leaf and aerial parts of $T$. villosa showed anti-oxidant activity when examined by DPPH assay method. This may be attributed due to the secondary metabolites like phenols, glycosides, tannins, reducing sugars, terpenoids, flavonoids present in the extract (Mani et al., 2017). In-vitro anti-oxidant activity of the different parts (Leaf, Stem, and Root) of T. tinctoria was studied by extracting with various solvents like hexane, chloroform, ethyl acetate, and ethanol. Among the various fractions tested using DPPH assay, the ethyl acetate fraction of stem of T. tinctoria exhibited maximum anti-oxidant activity (Rajaram and Suresh, 2011). Tephrosia apollinea was used to evaluate the anti-oxidant, anti-angiogenic, and cytotoxic activities. The results supported the ethnobotanical uses of the plant $T$. apollinea to cure the oxidative stress and paraneoplastic symptoms caused by the cancer (Hassan et al., 2014). The various organic extracts of leaf, stem, and root of $T$. apollinea were assayed for radical scavenging, total anti-oxidant capacity, antilipid peroxidation, and reduced glutathione, and was found to be ameliorating the oxidative stress developed during the generation of reactive oxygen species (Rizvi et al., 2018). The anti-oxidant and cytotoxic properties were evaluated using DPPH, ferric reducing anti-oxidant power (FRAP), reducing power assay, and anti-hemolytic assay of four major parts of methanolic extracts of T. purpurea including leaves, root, stem, and seed are investigated and compared. The results revealed that, among the four extracts studied, leaves extract showed the highest anti-oxidant activity, and there was no significant difference observed in anti-hemolytic activity. Leaves extract showed effective cytotoxicity on colorectal cancer cells and also had the higher total phenolic and flavonoid content, thus proving higher anti-oxidant and cytotoxic activities of leaf extract when compared with other extracts (Padmapriya et al., 2017).

\section{Anti-ulcer activity}

The ethanolic extract of T. calophylla leaves is reported to have anti-ulcer activity, when investigated using pylorus ligation, ethanol induced, and indomethacin-induced ulcer models. The extract was tested at two different doses. The results revealed that in all the three models, the extract showed dose dependent reduction in gastric volume, free acidity, ulcer index, and total acidity, thus proving the potential anti-ulcer activity. This activity is may be due to anti-secretory property of flavonoids present in the extract (Divya et al., 2011). The aqueous extract of roots of $T$. purpurea was evaluated for anti-ulcer activity using different models of gastric and duodenal ulceration in rats. The results suggested that the extract possesses significant anti-ulcer property which could be either due to cytoprotective action of the drug or by strengthening of gastric and duodenal mucosa, and thus enhancing mucosal defense (Deshpande et al., 2003).

\section{Purgative activity}

An investigation was carried out to analyze the stimulant effect on the Gastro Intestinal Tract (GIT) smooth muscles of methanolic extract of $T$. vogelii. This was demonstrated on the isolated rabbit jejunum which increased the contractions of intestinal smooth muscle. The extract, potentiates the contractile effect of acetylcholine (ACh) on intestinal smooth muscle by acting through the muscarinic cholinergic receptors, involving 
the mobilization of extracellular calcium ions. This result strongly provides the evidence for the purgative activity of $T$. vogelii (Dzenda et al., 2007; 2015).

\section{Anti-hyperlipidemic activity}

Different parts of the plant like stem, root, leaves, and whole plant also (excluding leaves) extracts of $T$. purpurea were screened for the anti-hyperlipidemic activity. It decreased the TC, TG, low-density lipoprotein, very low-density lipoprotein, and increased high-density lipoprotein levels, thus providing a significant evidence that the plant extract processes anti-hyperlipidemic activity by the inhibition of $\beta$-Hydroxy $\beta$-methylglutaryl-CoA (HMG-CoA) reductase enzyme (Dalwadi and Patani, 2014).

\section{Anti-cancer activity}

Tephrosia purpurea exhibited better anti-cancer activity when tested using human MCF 7 cell lines (estrogen receptor dependent and carries the tumor suppressor p53 gene), an in-vitro method. Mainly due to the presence of flavonoids, this genus exhibits the chemo preventive role which effects proliferation and angiogenesis (Gulecha and Sivakuma, 2011). The other species, T. apollinea also demonstrated the anti-cancer activity. After carrying out many investigations, it is evident that the plants are a good source of anti-cancer agents. A prenylated flavone, isoglabratephrin was isolated using bioassay guided technique from the aerial parts of T. apollinea. The three human cancer cell lines, namely, prostate (PC3), pancreatic (PANC-1), colon (HCT116), and one normal cell line (human fibroblast) were used for the study. It was observed that the isoglabratephrin displayed inhibitory activity against proliferation of PC3 and PANC-1 by inducing chromatin dissolution, nuclear condensation, and fragmentation, thus providing an evidence to treat human prostate and pancreatic malignancies (Hassan et al., 2017).

\section{Anti-fungal activity}

Tephrosia purpurea exhibited anti-fungal activity. This was found against 61 endophytic fungus strains with different colony morphologies isolated from the leaves, stem, and root of T. purpurea. Anti-fungal activity when measured by dual culture testing, out of 61 isolates, depending on the colony morphologies, the isolates exhibited broadest anti-fungal spectrum of activity, hence proving promising anti-fungal activity of the bioactive components present in T. purpurea (Luo et al., 2015). Tephrosia hildebrandtii showed anti-fungal activity against Cladosporium cucumerinum. The activity was found to be related to a chemical constituent isolated from its roots (Lwande et al., 1985). Tephrosia tinctoria also showed activity against Aspergillus niger and Candida albicans (Lakshmi et al., 2010).

\section{Anti-bacterial activity}

Tephrosia purpurea was found to possess anti-bacterial activity. The ethanolic extract from the roots was tested against three standard cultures Staphylococcus aureus, Pseudomonas aeruginosa, and Escherichia coli. The extracts were subjected to the minimum inhibitory concentration agar dilution method (Touqeer et al., 2013). Various studies were conducted on different kinds of microorganisms and those studies suggested that the methanolic extract of $T$. purpurea exhibited anti-microbial activity when tested on Bacillus subtilis, S. aureus, and Micrococcus luteus, the Gram-positive bacteria and the Gram-negative including E. coli, Pseudomonas aeruginosa, and Salmonella typhimurium. Also, the root extracts of T. purpurea, showed antimicrobial activity against $P$. aeruginosa and no activity against $S$. aureus and E. coli. The chloroform root extract of T. calophylla were tested for anti-bacterial and anti-fungal activity and showed moderate activity. The activity of the extracts increased with increasing concentrations (Abayasekara et al., 2009; Ramadevi, et al., 2014). The study was conducted to analyze the anti-bacterial activity of the bark of $T$. vogelii when tested using Bacillus cereus, E. coli, Salmonella typhi, Streptococcus pyogenes, Serratia marcescens, Serratia liquefaciens, Enterobacter aerogenes, and Staphylococcus epidermidis (Hu et al., 2011). The various extracts of $T$. villosa roots showed a moderate anti-bacterial and anti-fungal activity (Ganapaty et al., 2008).

\section{Anthelmintic activity}

The ethanolic extract of $T$. calophylla roots was screened for anthelmintic activity at various concentrations against adult Indian earthworm, Pheretimaposthuma, as it shows anatomical and physiology resemblance with intestinal round worm's parasite of human beings. The results obtained in this study proved that the efficacy of ethanolic extract $T$. calophylla taken at the dose of $100 \mathrm{mg} / \mathrm{ml}$ showed significant anthelmintic activity and it is a dose dependent activity which may be due to the presence of flavonoids (Devi et al., 2017). In another study, the methanolic and aqueous leaf extract of T. purpurea also demonstrated in invitro anthelmintic activity (Manjula et al., 2013).

\section{Larvicidal activity}

Extensive work has been done on Tephrosia as an agent to control the population of insects harmful to animals and plants. The larvicidal activities of $T$. egregia extracts and its major component, dehydrorotenone, were tested against Aedes aegypti larvae. The hexane extract of stems of $T$. egregia showed potent larvicidal activity (Arriaga et al., 2009). The larvicidal activity of petroleum ether and ethyl acetate extract of $T$. purpurea was tested against the larvae of Culex quinquefasiciatus thus proving to be the most promising, more selective and biodegradable agent (Kumar et al., 2012). The ethanol extract of roots, stems, leaves, and pods and some fractions of T. toxicaria were tested for lavicidal activity with the larvae of $A$. aegypti. It was found that rotenoids from $T$. toxicaria were responsible for larvicidal activity (Santiago et al., 2012). The extracts of T. villosa and T. pumila also possess larvicidal activity and therefore can be used to control mosquitoes (Kidukuli et al., 2015). The oil obtained from Tephrosia cinerea showed larvicidal activity against $A$. aegypti larvae (Arriaga et al., 2008). Flavonoids from the seedpods of T. elata and Tephrosia aequilata were found to possess anti-plasmodial and larvicidal activity. Tephrosia elata showed significant anti-feedant activity against $M$. testulalis, S. exempta and E. sacchariana (Atilaw et al., 2017; Muiva et al., 2009).

\section{Miscellaneous activities}

The anti-feedant activity is attributed due to the presence of rotenoid compounds. The roots of Tephrosia hidebrandtii also possess anti-feedant activity against the pest, Maruca testulalis (Lwande et al., 1985). The naturally occurring novel compound, 
benzofuran was isolated from the plant $T$. purpurea confirmed its suppressive activity toward $\mathrm{H}_{1}$ Histamine receptor gene expression (Shill et al., 2015). The prenylated flavonoids isolated from $T$. apollinea was tested for its toxic and anti-feedant activities against three major coleopteran pests of stored grains and the results revealed that there was a significant reduction in the relative growth rate, consumption rate, and efficiency of conversion of ingested food by all insects (Nenaah, 2014). The three flavonoids were isolated from the T. tinctoria roots and was tested for in-vitro anti-protozoal activity using cell line L-6 (rat skeletal muscle myoblasts). The flavonoids showed the potential to inhibit the parasitic protozoa namely, Trypanosoma, Leishmania, and Plasmodium. Out of the three flavonoids studied, 2-hydroxy tephrosin and tephrinone exhibited moderate activity against both Tephrosia brucei and Tephrosia cruzi, mild activity against Leishmania donovani and no activity against Plasmodium falciparum (Ganapaty et al., 2009b). When the ethyl acetate extracts of leaf, stem, and root of T. tinctoria were compared with the leaf, stem, and root callus revealed that it has potent anti-oxidant and anti-proliferative activity and the callus culture can be used to produce the bioactive compounds due to the endemic nature of the plant. The apoptotic cell death was observed through DNA fragmentation analysis in HepG2 cells treated with T.tinctoria (Rajaram et al., 2013). The HPTLC analysis, anti-oxidant, and anti-gout activity of T. purpurea extract were investigated by 2,2'-azino-bis(3-ethylbenzothiazoline-6sulphonic acid), DPPH, FRAP radical scavenging assays, and antigout activity by cow milk xanthine oxidase. The results showed significant xanthine oxidase inhibitory activity and revealed an inhibition greater than $50 \%$ and $\mathrm{IC}_{50}$ values below the standard thus proving their active constituents are useful against inflammation and gout (Nile and Park, 2014). Aqueous extract of T. purpurea was used to investigate the cardiovascular complications and cataract associated in streptozotocin induced diabetic rats. The data obtained from the study suggested that the extract prevents not only the streptozotocin-induced metabolic abnormalities but also cardiovascular abnormalities and reduces the risk of development of cataract (Bhadada and Goyal, 2015). A novel benzofuran, 4-methoxybenzofuran-5-carboxamide (MBCA) from T. purpurea and its chemical synthesis was investigated for its anti-allergic activity and the mechanism was evaluated, works on the mechanism of MBCA on phorbol 12-myristate-13-acetate or histamine induced upregulation of $\mathrm{H}_{1} \mathrm{R}$ gene expression in HeLa cells (Shill et al., 2016). The efficacy of T. purpurea in the prevention of generation of free radicals and in preventing various diseases like cataract in the lens of selenite-induced cataract models. Morphological evaluation of the $T$. purpurea treated rats lens revealed the normal transparent lens, reduction in nuclear opacity, improvement in the insoluble proteins, protein sulfydryl, total nitrate, calcium levels, decreased malondialdehyde levels but also prevented the loss of reduced glutathione levels (Bhadada et al., 2016).

\section{CONCLUSION}

The present extended review on the genus Tephrosia shows number of phytoconstituents like flavonoids, terpenoids, sterols, rotenoids, etc which is present in different species and also their diverse pharmacological activities such as hepatoprotective, anti-diabetic, anti-oxidant, anti-hyperlipidemic, anti-ulcer, antibacterial, anti-fungal, larvicidal, anti-inflammatory, wound healing, anti-cancer, and anti-feedant activities of few species. Among all the phytoconstituents, flavonoids were the major constituent isolated from most of the species. Hence, the present review summarized the significant research works conducted on the Tephrosia genus, and its phytoconstituents and biological uses which can be further studied to explore potent bioactive molecules in search of newer herbal drugs.

\section{CONFLICT OF INTEREST}

All the authors declared there is no conflict of interest.

\section{REFERENCES}

Abayasekara CL, Rangama BNLD, Panagoda GJ, Senanayake MRDM. Anti-microbial activity of Tephrosia purpurea (Linn.) Pers. and Mimusops elengi (Linn.) against some clinical bacterial isolates. J Natl Sci Found, 2009; 37(2):139-45.

Adinarayana K, Jayaveera KN, Rao PM, Chetty CM, Sandeep DK, Swetha C, Saleem TSM. Acute toxicity and hepatoprotective effect of methanolic extract of Tephrosia calophylla. Res J Med Plant, 2011; 5(3):266-73.

Ahmed Hassan LE, Khadeer Ahamed MB, Abdul Majid AS, Iqbal MA, Al Suede FS, Haque RA, Ismail Z, Ein OC, Majid AM. Crystal structure elucidation and anti-cancer studies of (-)-pseudosemiglabrin: a flavanone isolated from the aerial parts of Tephrosia apollinea. PLoS One, 2014; 9(3):e90806.

Al-Ghamdi FA. Morphological Diversity of Some Tephrosia Species (Fabaceae) in Saudi Arabia. Am J Plant Sci, 2013; 4(3):543-48.

Andrei CC, Ferreira DT, Faccione M, de Moraes LA, de Carvalho MG, Braz-Filho R. C-prenylflavonoids from roots of Tephrosia tunicata. Phytochemistry, 2000; 55(7):799-804.

Arriaga AM, Malcher GT, Lima JQ, Magalhaes FE, Gomes TMBM, Da Conceicao M, Oliveira F, Andrade-Neto M, Mafezolli J, Santiago GM. Composition and larvicidal activity of the essential oil from Tephrosia cinerea Pers. JEOR, 2008; 20(5):450-1.

Arriaga AM, Lima JQ, e Vasconcelos JN, de Oliveira MC, Lemos TL, Fonseca AM, Malcher GT, Santiago GM, Mafezoli J, Braz-Filho R. Anti-oxidant and larvicidal activities of Tephrosia egregia Sandw against Aedes aegypti. Nat Prod Commun, 2009; 4(4):529-30.

Atilaw Y, Duffy S, Heydenreich M, Muiva-Mutisya L, Avery VM, Erdelyi M, Yenesew A. Three Chalconoids and a Pterocarpene from the Roots of Tephrosia aequilata. Molecules, 2017; 22(2):E318.

Babayemi J, Bamikole M. Supplementary value of Tephrosia bracteolata, Tephrosia candida, Leucaena leucocephala and Gliricidia sepium hay for West African dwarf goats kept on range. J Cent Eur Agric, 2006; 7(2):323-8.

Bhadada SV, Goyal RK. Effect of aqueous extract of Tephrosia purpurea on cardiovascular complications and cataract associated with streptozotocin-induced diabetes in rats. Indian J Pharm Sci, 2015; 77(5):522-9.

Bhadada SV, Bhadada VJ, Goyal RK. Preventive effect of Tephrosia purpurea on selenite-induced experimental cataract. Curr Eye Res, 2016; 41(2):222-31.

Bhadada SV, Goyal RK. Effect of flavonoid rich fraction of Tephrosia purpurea (Linn.) Pers. on complications associated with streptozotocin-induced type I diabetes mellitus. Indian J Exp Biol, 2016; 54(7):457-66.

Bhadada SV, Vyas VK, Goyal RK. Protective effect of Tephrosia purpurea in diabetic cataract through aldose reductase inhibitory activity. Biomed Pharmacother, 2016; 83:221-8.

Chen Y, Yan T, Gao C, Cao W, Huang R. Natural products from the genus Tephrosia. Molecules, 2014; 19(2):1432-58.

Dagne E, Dinku B, Gray AI, Waterman PG. Pumilaisoflavones A and B from the seed pods of Tephrosia pumila. Phytochemistry, 1988; 27(5):1503-5. 
Dagne E, Yenesew A, Waterman PG. Flavonoids and isoflavonoids from Tephrosia fulvinervis and Tephrosia pentaphylla. Phytochemistry, 1989; 28(11):3207-10.

Dagne E, Mammo W, Sterner O. Flavonoids of Tephrosia polyphylla. Phytochemistry, 1992; 31(10):3662-3.

Dalwadi PP, Patani P. Anti-hyperlipidemic activity of Tephrosia purpurea plant extracts in Poloxomer 407 induced hyperlipidemic rats. IJPR, 2014; 4(4):186-93.

Deshpande SS, Shah GB, Parmar NS. Anti-ulcer activity of Tephrosia purpurea in rats. Indian J Pharmacol, 2003; 35(3):168-72.

Devi BN, Swarnalatha D, Gopinath C, Adinarayana K. Anthelmintic activity of Tephrosia calophylla. J Pharm Res, 2017; 11(1):35-8.

Divya S, Haritha V, Prasad KVS. Evaluation of Tephrosia calophylla for anti-ulcer activity in experimental rats. Pharmacologyonline, 2011; 3:573-85.

Dzenda T, Ayo JO, Adelaiye AB, Adaudi AO. Mechanism of action of Tephrosia vogelii leaf extract on isolated rabbit jejunum. J Herbs Spices Med Plants, 2007; 13(1):71-82.

Dzenda T, Ayo JO, Adelaiye AB, Adaudi AO. Methanol extract of Tephrosia vogelii leaves potentiates the contractile action of acetylcholine on isolated rabbit jejunum. Asian Pac J Trop Biomed, 2015; 5(9):744-7.

Falak AH, Shoeb A. A new epoxyflavanone from Tephrosia hamiltonii1. Planta Med, 1987; 53(2):220-1.

Ganapaty S, Nyamathulla S, Srilakshmi GVK, Prasad R. Chemical and Anti-microbial Studies of the Roots of Tephrosia villosa (L) Pers. Asian J Chem, 2008; 20(6):4498-502.

Ganapaty S, Lakshminarayana K, Lakshmi P, Thomas PS. Antiprotozoal and cytotoxicity assays of the isolates of Tephrosia tinctoria. Asian J Chem, 2009a; 21(2):1007-10.

Ganapaty S, Srilakshmi GV, Pannakal ST, Rahman H, Laatsch H, Brun R. Cytotoxic benzil and coumestan derivatives from Tephrosia calophylla. Phytochemistry, 2009b; 70(1):95-9.

Gomez-Garibay F, Quijano L, Garcia G, Calderon JS, Rios T. A prenylated flavan from Tephrosia madrensis. Phytochemistry, 1983; 22(5):1305-6.

Gomez-Garibay F, Calderón JS, Quijano L, Domínguez M, Ríos T. Viridiflorin, an isoflavone from Tephrosia viridiflora. Phytochemistry, $1985 ; 24(5): 1126-8$.

Gomez-Garibay F, Quijano L, Rios T. Flavanones from Tephrosia leiocarpa. Phytochemistry, 1991; 30(11):3832-4.

Gomez-Garibay F, Quijano L, Hernandez C, Rios T. Enantiomultijugin, a flavone from Tephrosia viciodes. Phytochemistry, 1992; 31(8):2925-6.

Gomez-Garibay F, Calderón JS, Arciniega MD, Cespedes CL, Tellez-Valdes O, Taboada J. An unusual isopropenyldihydrofuran biflavanol from Tephrosia crassifolia. Phytochemistry, 1999; 52(6):1159-63.

Gomez-Garibay F, Tellez-Valdez O, Moreno-Torres G, Calderon JS. Flavonoids from Tephrosia major. A new prenyl- $\beta$-hydroxychalcone. Z Naturforsch C, 2002; 57(7-8):579-83.

Gora RH, Baxla SL, Kerketta P, Patnaik S, Roy BK. Hepatoprotective activity of Tephrosia purpurea against arsenic induced toxicity in rats. Indian J Pharmacol, 2014; 46(2):197-200.

Gulecha V, Sivakuma T. Anti-cancer activity of Tephrosia purpurea and Ficus religiosa using MCF 7 cell lines. Asian Pac J Trop Med, 2011; 4(7):526-9.

Hassan LE, Ahamed MB, Majid AS, Baharetha HM, Muslim NS, Nassar ZD, Majid AM. Correlation of anti-angiogenic, anti-oxidant and cytotoxic activities of some Sudanese medicinal plants with phenolic and flavonoid contents. BMC Complement Altern Med, 2014; 14:406.

Hassan LE, Dahham SS, Fadul SM, Umar MI, Majid AS, Khaw KY, Majid AM. Evaluation of in vitro and in vivo anti-inflammatory effects of (-)-pseudosemiglabrin, a major phytoconstituent isolated from Tephrosia apollinea (Delile) DC. J Ethnopharmacol, 2016; 193:312-20.
Hassan LEA, Iqbal MA, Dahham SS, Tabana YM, Ahamed MBK, Majid AMSA. Colorectal, prostate and pancreas human cancers targeted bioassay-guided isolations and characterization of chemical constituents from Tephrosia apollinea. Anti-Cancer Agents Med Chem, 2017; 17(4):590-8.

Hegazy ME, El-Hamad H Mohamed A, El-Halawany AM, Djemgou PC, Shahat AA, Pare PW. Estrogenic activity of chemical constituents from Tephrosia candida. J Nat Prod, 2011; 74(5):937-42.

Hu LZ, Li XH, Ma YQ, Yu X. Study on bacteriostatic activity of extracts in different solvents from Tephrosia vogelii Hook f. seeds. Sci Technol Food Ind, 2011; 32(1):85-8.

Ingham JL, Markham KR. Tephrocarpin, a pterocarpan phytoalexin from Tephrosia bidwilli and a structure proposal for acanthocarpan. Phytochemistry, 1980; 21(12):2969-72.

Khalafalah AK, Yousef AH, Esmail AM, Abdelrazik MH, Hegazy ME, Mohamed AE. Chemical constituents of Tephrosia purpurea. Pharmacognosy Res, 2010; 2(2):72-5.

Khan HA, Chandrasekharan I, Ghanim A. Falciformin, a flavanone from pods of Tephrosia falciformis. Phytochemistry, 1986; 25(3):767-8.

Kidukuli AW, Maregesi SM, Saria J, Otieno NJ, Lawi Y, Nondo RS, Innocent EM, Mlimbila J, Mihale MJ, Moshi MJ. Larvicidal efficacy of some Tephrosia species extracts against Anopheles Gambiae Ss and Culex Quinquefasciatus Say. SpatulaDD, 2015; 5(1):21-5.

Kumar D, Dhamodaran P, Nilani P, Balakrishnan N. Larvicidal activity of Tephrosia purpurea,(L) against the Larvae of Culex quinquefasiciatus. J Appl Pharm Sci, 2012; 2(7):219-21.

Kumar KDV, Jayaveera KN, Kumar GS. Anti-inflammatory and anti-nociceptive properties of Tephrosia falciformis root extract. Pharmacologyonline, 2007; 2:371-84.

Lakshmi P, Khan PA, Reddy PN, Lakshminarayana K, Ganapaty S. Genetic relationship among Tephrosia species as revealed by RAPD analysis. Asian J Biol Sci, 2008; 1(1):1-10.

Lakshmi P, Bobbarala V, Ganapaty S. Chemical and biological evaluation of the leaves of Tephrosia tinctoria PERS. Int J Chem Anal Sci, 2010; 1(1):14-7.

Li XH, Huang XL, YU X, Zhu XY, Huang XH. Study on scavenging free radial activity of extracts from Tephrosia vogelii Hook $\mathrm{f}$. seeds. Food Res Dev, 2010; 1:5-9.

Lodhi S, Pawar RS, Jain AP, Singhai AK. Wound healing potential of Tephrosia purpurea (Linn.) Pers. in rats. J Ethnopharmacol, 2006; 108(2):204-10.

Lodhi S, Jain A, Jain AP, Pawar RS, Singhai AK. Effects of flavonoids from Martynia annua and Tephrosia purpurea on cutaneous wound healing. Avicenna J Phytomed, 2016;6(5):578-91.

Luo ZP, Lin HY, Ding WB, He HL, Li YZ. Phylogenetic diversity and anti-fungal activity of endophytic fungi associated with Tephrosia purpurea. Mycobiology, 2015; 43(4):435-43.

Lwande W, Hassanali A, Njoroge PW, Bentley MD, Monache FD, Jondiko JI. A new 6a-hydroxypterocarpan with insect anti-feedant and anti-fungal properties from the roots of Tephrosia hildebrandtii Vatke. Int J Trop Insect Sci, 1985; 6(4):537-41.

Lwande W, Bentley MD, Hassanali A. The structure of hildecarpin, an insect anti-feedant 6a-hydroxypterocarpan from the roots of Tephrosia hildebrandtii Vatke. Int J Trop Insect Sci, 1986; 7(4):501-3.

Machocho AK, Lwande W, Jondikoa JI, Moreka LVC, Hassanali A. Three new flavonoids from the root of Tephrosia emoroides and their anti-feedant activity against the larvae of the spotted stalk borer Chilo partellus Swinhoe. Pharm Biol, 1995; 33(3):222-7.

Madhusudhana J, Reddy RN, Reddy BA, Reddy MV, Gunasekar D, Deville A, Bodo B. Two new geranyl flavanones from Tephrosia villosa. Nat Prod Res, 2010; 24(8):743-9.

Maldini M, Montoro P, Macchia M, Pizza C, Piacente S. Profiling of phenolics from Tephrosia cinerea. Planta Med, 2011; 77(16):1861-4. 
Mani AS, Prasad YR, Siddhanandam AS, Aparna B. Phytochemical and anti-oxidant activity screening of chloroform leaf and aerial part extracts of Tephrosia villosa. WJPLS, 2017; 3(9):181-4.

Manjula RR, Spandana U, Anand TJ, Sudheer M. In vitro anthelmintic activity of aqueous and methanolic leaf extract of Tephrosia purpurea Linn. IJRPC, 2013; 3(1):12-4.

Martinez RM, Zarpelon AC, Zimermann VV, Georgetti SR, Baracat MM, Fonseca MJ, vicentini FTM, Moreira IC, Andrei CC, Verri WA, Casagrande R. Tephrosia sinapou extract reduces inflammatory leukocyte recruitment in mice: effect on oxidative stress, nitric oxide and cytokine production. Rev Bras Farmacogn, 2012; 22(3):587-97.

Martinez RM, Zarpelon AC, Domiciano TP, Georgetti SR, Baracat MM, Moreira IC, Andrei CC, Verri WA, Casagrande R. Antinociceptive effect of Tephrosia sinapou extract in the acetic acid, phenylp-benzoquinone, formalin, and complete Freund's adjuvant models of overt pain-like behavior in mice. Scientifica (Cairo), 2016; 2016:8.

Muazu J, Kaita AH. A review of traditional plants used in the treatment of epilepsy amongst the Hausa/Fulani tribes of northern Nigeria. Afr J Tradit Complement Altern Med, 2008; 5(4):387-90.

Muiva LM, Yenesew A, Derese S, Heydenreich M, Peter MG, Akala HM, Eyase F, Waters NC, Mutai C, Keriko JM, Walsh D. Antiplasmodial $\beta$-hydroxydihydrochalcone from seedpods of Tephrosia elata. Phytochem Lett, 2009; 2(3):99-102.

Nenaah GE. Toxic and anti-feedant activities of prenylated flavonoids isolated from Tephrosia apollinea L. against three major coleopteran pests of stored grains with reference to their structure-activity relationship. Nat Prod Res, 2014; 28(24):2245-52.

Nile SH, Park SW. HPTLC analysis, anti-oxidant and anti-gout activity of Indian plants. Iran J Pharm Res, 2014; 13(2):531-9.

Padmapriya R, Ashwini S, Raveendran R. In vitro anti-oxidant and cytotoxic potential of different parts of Tephrosia purpurea. Res Pharm Sci, 2017; 12(1):31-7.

Peng Y, Chen Y, Gao C, Yan T, Cao W, Huang R. A new 1, 2-ethanedione benzofurane derivative from Tephrosia purpurea. Nat Prod Res, 2014; 28(20):1705-8.

Prabhakar P, Vanangamudi A, Gandhidasan R, Raman PV. Hookerianin: a flavone from Tephrosia hookeriana. Phytochemistry, 1996; 43(1):315-6.

Praveena R, Amarnath S, Jegadeesan M. Anti-inflammatory activity of Tephrosia purpurea. Root. IJPPR, 2011; 3(4):93-4.

Rajani P, Sarma N. A coumestone from the roots of Tephrosia hamiltonii. Phytochemistry, 1988; 27(2):648-9.

Rajaram K, Suresh KP. In-vitro anti-oxidant and anti-diabetic activity of Tephrosia tinctoria PERS.: an endemic medicinal plant of South India. J Pharm Res, 2011; 4(3):891-3.

Rajaram K, Moushmi M, Prakash MVD, Kumpati P, Ganasaraswathi M, Sureshkumar P. Comparative bioactive studies between wild plant and callus culture of Tephrosia tinctoria pers. Appl Biochem Biotechnol, 2013; 171(8):2105-20.

Rajaram K, Aiswarya DC, Sureshkumar P. Green synthesis of silver nanoparticle using Tephrosia tinctoria and its anti-diabetic activity. Mater Lett, 2015; 138:251-4.

Ramadevi D. Anti-microbial Activity of Tephrosia calophylla bedd. roots. World J Pharm Pharm Sci, 2014; 3(7):633-7.

Ramesh C, Rani PA. In vivo and in vitro evaluation of Tephrosia calophylla for anti-diabetic properties. Int J Pham Pharm Sci, 2018; 10(6):138-44.

Rao EV, Prasad YR. Prenylated flavonoids from Tephrosia spinosa. Phytochemistry, 1992; 32(1):183-5.

Reddy GR, Rammohan A, Munikishore R, Gunasekar D. A new 5-deoxyflavonol from Tephrosia tinctoria. J Chem Pharm Res, 2014; 6(9):34-6.

Ribeiro WH, Vasconcelos JN, Arriaga A, de Oliveira MC, Andrade-Neto M, Lemos TL, Santiago GM, Nascimento RF, Mafezoli J. Tephrosia toxicaria Pers essential oil: chemical composition and larvicidal activity. Nat Prod Commun, 2006; 1(5):391-3.
Rizvi TS, Khan AL, Ali L, Al-Mawali N, Mabood F, Hussain J, Adnan M, Al-Harrasi A. In vitro oxidative stress regulatory potential of Citrullus colocynthis and Tephrosia apollinea. Acta Pharm, 2018; 68(2):235-42.

Roger JP, Brian SM. Anti-epileptic drug. In: Katzung BG (ed.) Basic and clinical pharmacology. Prentice Hall International (UK) Ltd, London, UK, pp 331-42, 1996.

Sandhya S, Venkatramana K, Ravindran, Vinod, Sunitha, CH, Murali, Krishna. Pharmacognostical standardization of Tephrosia maxima Pers root. Pharmacognosy J, 2011; 3(26):25-33.

Santiago GM, Lima JQ, Mafezoli J, Lemos TL, Silva FR, Lima MA, Pimenta AT, Braz-Filho R, Arriaga AM, Cesarin-Sobrinho D. Rotenoids from Tephrosia toxicaria with larvicidal activity against Aedes aegypti, the main vector of dengue fever. Quim Nova, 2012; 35(6):1097-100.

Shah R, Parmar S, Bhatt P, Chanda S. Evaluation of hepatoprotective activity of ethyl acetate fraction of Tephrosia purpurea. Pharmacologyonline, 2011; 3:188-94.

Shill MC, Das AK, Itou T, Karmakar S, Mukherjee PK, Mizuguchi H, Kashiwada Y, Fukui H, Nemoto H. The isolation and synthesis of a novel benzofuran compound from Tephrosia purpurea, and the synthesis of several related derivatives, which suppress histamine $\mathrm{H} 1$ receptor gene expression. Bioorg Med Chem, 2015; 23(21):6869-74.

Shill MC, Mizuguchi H, Karmakar S, Kadota T, Mukherjee PK, Kitamura Y, Kashiwada Y, Nemoto H, Takeda N, Fukui H. A novel benzofuran, 4-methoxybenzofuran-5-carboxamide, from Tephrosia purpurea suppressed histamine $\mathrm{H} 1$ receptor gene expression through a protein kinase $\mathrm{C}-\delta$-dependent signaling pathway. Int Immunopharmacol, 2016; 30:18-26.

Smalberger TM, Van Den Berg AJ, Vleggaar R. Flavonoids from Tephrosia-VI: The structure of semiglabrin and semiglabrinol. Tetrahedron, 1973; 29(19):3099-104.

Smalberger TM, Vleggaar R, Weber JC. Flavonoids from Tephrosia-VII: the constitution and absolute configuration of lupinifolin and lupinifolinol, two flavanones from Tephrosia lupinifolia Burch (DC). Tetrahedron, 1974; 30(21):3927-31.

Smalberger TM, Vleggaar R, Weber JC. Flavonoids from Tephrosia-VIII: the structure of elongatin, an isoflavone from Tephrosia elongata E. Mey. Tetrahedron, 1975; 31(18):2297-301.

Soni K, Kumar PS, Saraf MN. Anti-oxidant activity of fraction of Tephrosia purpurea Linn. Indian J Pharm Sci, 2006; 68(4):456-60.

Stevenson PC, Kite GC, Lewis GP, Forest F, Nyirenda SP, Belmain SR, Sileshi GW, Veitch NC. Distinct chemotypes of Tephrosia vogelii and implications for their use in pest control and soil enrichment. Phytochemistry, 2012; 78:135-46.

Touqeer S, Saeed MA, Ajaib M. A review on the phytochemistry and pharmacology of genus Tephrosia. Phytopharmacology, 2013; 4(3):598-637.

Venkataratnam G, Rao EV, Vilain C. Flavonoids of Tephrosia procumbens - revised structure for praecansone A and conformation of praecansone B. J Chem Soc Perkin Trans I, 1987; 12:2723-7.

Verma N, Neeraj, Singh J. Evaluation of hepatoprotective activity of Tephrosia purpurea Linn. stem. IEJSRJ, 2017; 2(7):1-6.

Vleggaar R, Smalberger TM, Van den Berg AJ. Flavonoids from Tephrosia-IX: the structure of multijugin and multijuginol. Tetrahedron, 1975; 31(20):2571-3.

How to cite this article:

Samuel VJ, Mahesh AR, Murugan V. Phytochemical and pharmacological aspects of Tephrosia genus: A brief review. J Appl Pharm Sci, 2019; 9(03):117-125. 